DOI: https://doi.org/10.46630/gped.2.2018.02

\title{
АНАЛИЗА ДЕЧИЈЕГ ТЕЛЕВИЗИЈСКОГ ПРОГРАМА ЈАВНОГ МЕДИЈСКОГ СЕРВИСА СРБИЈЕ
}

\author{
Марија Вујовић ${ }^{1}$, Анка Михајлов Прокоповић \\ Универзитет у Нишу, Филозофски факултет у Нишу, \\ Департман за комуникологију и новинарство
}

\begin{abstract}
Ancmpaкm: Дечији телевизијски програм је елитни и скуп програм намењен најосетљивијем и најзахтевнијем аудиторијуму - деци. Он представља престиж једне телевизијске куће, али и програмску обавезу Јавног медијског сервиса Србије ${ }^{2}$. Његова заступљеност и разноврсност би могла бити индикатор развијености јавног сервиса. Предмет истраживања у раду је положај дечијег програма Јавног медијског сервиса Србије. Циљ рада је истражити квантитативну заступљеност дечијег програма у укупном програмском садржају. Анализа је спроведена на основу резултата истраживања Регулаторног тела за електронске медије Републике Србије. Истраживачко питање је да ли обим емитованог дечијег програма на Јавном медијском сервису Србије задовољава програмске стандарде у складу са регулативом? У раду ће бити анализирана и регулатива у Србији која се односи на дечији програм. Методологија у раду је анализа садржаја докумената, квантитативна статистичка метода и компаративан метод. Резултати показују да јавни медијски сервис не испуњава у довољној мери обавезу емитовања програма намењеног деци.
\end{abstract}

Кључне речи: дечији програм, Јавни медијски сервис Србије, програмски стандарди

\section{Увод}

Према подацима Републичког завода за статистику Републике Србије из 2018. године 3 , 99,1 одсто домаћинстава у Србији поседује телевизор, и то

\footnotetext{
${ }^{1}$ marija.vujovic@filfak.ni.ac.rs

${ }^{2}$ Радио-телевизија Србије (РТС) као јавно, државно предузеће у које су интегрисане Радиотелевизија Београд, Радио-телевизија Нови Сад и Радио-телевизија Приштина, основано је 1991. године. Законом о радиодифузији, који је усвојен 2002. године, РТС је постао јавни радиодифузни сервис, тачније, формирана су два јавна сервиса: републички - Радио-телевизија Србије (РТС) и покрајински - Радио-телевизија Војводине (РТВ).

3 Доступно на: http://publikacije.stat.gov.rs/G2018/Pdf/G201816013.pdf, посећено 20. новембра 2018. године.
} 
је најчешће коришћени уређај за праћење медија. Резултати мерења Nielsen Audience Measurement, у 2016. години, показују да је телевизија најпраћенији медиј, са просечним недељним аудиторијумом од 6,9 милиона гледалаца 4 , што грађане Србије смешта у светски врх по времену проведеном испред телевизијских екрана. У 2017. години телевизију су гледали просечно 313 минута дневно. Ипак, од свих узрасних категорија, деца ${ }^{5}$ најмање гледају телевизију, али су најосетљивија категорија друштва. „... Телевизија оставља многобројне последице на њихово понашање и поглед на свет, као и на њихов когнитивни и емоционални свет" (Lemiš, 2008: 275). Због тога је свако истраживање програмског садржаја за децу оправдано.

Истраживања показују да је Радио-телевизија Србије годинама уназад најгледанија телевизија у Србији․ За разлику од комерцијалних емитера (ТВ Пинк, О2.ТВ, Прва, Национална Хепи ТВ), „Јавни сервис је непрофитна, независна радио-телевизијска организација, основана у име опште јавности и финансирана из јавних прихода, која разноврсним, уравнотеженим, висококвалитетним програмима задовољава потребе највећег могућег броја грађана, односно најшире јавности, непристрасно и без дискриминације” (Veljanovski, 2005: 28).

Законом о електронским медијима7, чланом 4, и Законом о јавним медијским сервисима ${ }^{8}$, чланом 3 , дефинисана је делатност јавног медијског сервиса: „Основна делатност јавног медијског сервиса у функцији је остваривања јавног интереса дефинисаног овим законом, а подразумева производњу, куповину, обраду и објављивање радио, телевизијских и мултимедијалних садржаја, нарочито информативних, образовних, културно-уметничких, дечијих, забавних, спортских, верских и других који су од јавног интереса за грађане, а који за циљ имају остваривање људских права и слобода, размену идеја и мишљења, неговање вредности демократског друштва, унапређивање политичке, полне, међунационалне и верске толеранције и разумевања, очување националног идентитета српског народа и националних мањина, као и пружање аудио и аудио-визуелних медијских услуга и објављивање електронских издања као услуга од јавног интереса". Чланом 7 истог Закона дефинисан је

\footnotetext{
4 Доступно на: https://serbia.mom-rsf.org/fileadmin/Editorial/Serbia/Documents/SRBIJA_POD_ LUPOM_IPSOSA_2016_1.pdf, посећено 20. новембра 2018. године.

${ }^{5}$ Конвенцијом Уједињених нација о правима детета, коју је Република Србија ратификовала 1990. године, дететом је дефинисано свако људско биће које није навршило осамнаест година живота.

${ }^{6}$ Радио-телевизију Србије, између осталог, чине телевизијски, радио-програми и интернет издање. Телевизијски програм, који ауторке истражују, чине РТС 1, РТС 2, РТС 3, РТС Свет, РТС ХД, РТС Драма, РТС Живот, РТС Коло, РТС Трезор, РТС Музика и РТС Полетарац. У раду су анализирана прва два програма, с обзиром на то да су они искључиви предмет анализе Регулаторног тела за електронске медије.
}

${ }^{7}$ Доступан на: https://www.paragraf.rs/propisi/zakon_o_elektronskim_medijima.html, посећено 21. новембра 2018. године.

8 Доступно на: https://www.paragraf.rs/propisi/zakon_o_javnim_medijskim_servisima.html, посећено 22. новембра 2018. године. 
и јавни интерес који остварује јавни медијски сервис, а то је: „Задовољавање потреба у информисању свих делова друштва без дискриминације, водећи рачуна нарочито о друштвено осетљивим групама као што су деца, омладина и стари, мањинске групе, особе са инвалидитетом, социјално и здравствено угрожени и др.”. Заштита деце и младих кроз подршку производњи медијских садржаја, гарантована је и Законом о јавном информисању и медијима ${ }^{9}$ чланом 15.

Конвенцијом Уједињених нација о правима детета регулисан је однос деце и медија. Чланом 13. одређено је да дете има право на слободу изражавања која обухвата и слободу да тражи, прима и даје информације и идеје свих врста, без обзира на границе, било усмено или у писаној форми или преко штампе, уметности или неког другог медија по избору детета. Чланом 17 одређено је да државе чланице признају значајну улогу средстава јавног информисања и омогућавају приступ детета информацијама и материјалима из различитих националних и међународних извора, посебно оних чији је циљ унапређење његовог социјалног, духовног и моралног добра и физичког и менталног здравља. У том циљу, државе чланице подстичу средства јавног информисања да шире информације и материјале од социјалног и културног интереса за дете, подстичу међународну сарадњу у производњи, размени и ширењу таквих информација и материјала из различитих културних, националних и међународних извора, подстичу објављивање и ширење дечијих књига, подстичу средства јавног информисања да посвете посебну пажњу лингвистичким потребама детета које припада мањинској групи или које је аутохтоног порекла и подстичу развој одговарајућих смерница за заштиту детета од информација и материјала који штете његовом добру.

Рад има за циљ да утврди да ли Јавни медијски сервис Србије поштује наведене медијске прописе када је реч о дечијем програму и какав је положај ове осетљиве, али и престижне врсте програма на РТС-у.

\section{1. Дечији телевизијски програм}

У Правилнику о мерилима за утврђивање висине накнаде за емитовање радио и/или телевизијског програма ${ }^{10}$, чланом 9, дефинисан је дечији програм. „Дечији програм подразумева дечије филмове у сопственој продукцији, уколико имају образовно-васпитни карактер: играни, цртани, анимирани, документарни, све студијске емисије у којима учествују деца (предшколска, основци), уколико имају образовно-васпитни карактер, музичке програме за децу и са децом у сопственој продукцији уколико имају образовно-васпитни карактер и остале програме чији су актери деца без обзира на жанр, у сопственој продукцији уколико имају образовно-васпитни карактер".

\footnotetext{
9 Доступно на: https://www.paragraf.rs/propisi/zakon_o_javnom_informisanju_i_medijima.html, посећено 22. новембра 2018. године.

${ }^{10}$ Доступно на: http://www.rem.rs/uploads/files/Pravilnici/3499-pravilnik-o-merilima-za-utvrdjivanjevisine-naknade.pdf, посећено 22. новембра 2018. године.
} 
Први дечији телевизијски програм снимљен је на најстаријој телевизији, британском јавном сервису (BВC). Како наводе у својим документима, деца су одувек била у срцу јавног сервиса. Најстарија емисија Дечији сат (Children's Hour), намењена деци, емитована је 1922. године на радију британског јавног сервиса, а први прави дечији програм на телевизији почео је 1946. године. Програм Дечији сат или За децу (Children's Hour, For the Children) емитован је уживо недељом поподне. Године 1950. почиње са радом и посебна дечија телевизија, а формирана је и редакција за дечији програм ${ }^{11}$.

Британско независно Регулаторно тело за комуникације (Ofcom) peдовно објављује резултате истраживања на тему дечијег телевизијског и програма на интернету ${ }^{12}$. Последњи разултати истраживања показали су да деца користе могућности које је дигитализација телевизије донела, као што је гледање на захтев. С друге стране, гледање телевизије уживо опада. Између 2010. и 2017, гледање телевизије опада за 40 одсто за децу од 4 до 9 година и за 47 одсто за децу узраста од 10 до 15,5 година. И садржаји за које су деца заинтересована су другачији. Најгледанији су Јутјуб (YouTube) и Нетфликс (Netflix). Рекорде гледаности држе емисије у којима актери отварају упаковане играчаке и демонстрирају игру са њима, затим снимци играња видео игара, описивање јутрањих рутина и сл. Осим британског јавног сервиса који и даље улаже у развој дечијих програма, комерцијални емитери у Великој Британији посустају. Истраживање открива три тренда: недостају оригинални, високо квалитетни програми, посебно намењени старијој деци; ограничен је број дечијих „чињеничних" програма који помажу деци да разумеју свет око себе и ограничен је распон дечијих програма који омогућавају деци Британије идентификацију, могућност да сагледају сопствене животе, у свим разноликостима.

Дечији програм у Србији је, у складу са законима који регулишу рад медија, и према Статуту РТС-а ${ }^{13}$, обавезан део програмског садржаја PTC-а. Историја прогама за децу Телевизије Београд је богата. На слово на слово аутора Душка Радовића, Невен Миле и Тимотија Бајфорда, Салаш у малом риту Арсена Диклића, Кочка, коика, коикииа Бранка Милићевића, само су неке од емисија чије се репризе и данас налазе у програмским шемама. Од почетка рада Телевизије Београд, 1958. године, програм намењен деци је препознат као значајан. Аутори Сибина Михељ и Симон Хукстабул (Sabina Mihelj и Simon Huxtable), упоређујући програмске шеме телевизија пет земаља Источне Европе (Источна Немачка, Совјетски Савез, Пољска, Румунија и Југославија), током недеље у октобру, у петогодишњим интервалима од 1960. до 1990. године, уочили су сличност у програмским блоковима: образовни и дечији програм током дана,

\footnotetext{
${ }^{11} \mathrm{O}$ историји дечијег програма британског јавног сервиса видети више на: https://www.bbc.co.uk/ historyofthebbc/research/programming/children-and-the-bbc, посећено 23. новембра 2018. године.

12 Доступно на: https://www.ofcom.org.uk/_data/assets/pdf_file/0023/116519/childrens-contentreview-update.pdf, посећено 23. новембра 2018. године.

${ }_{13}^{13}$ Доступно на: http://www.rts.rs/upload/storyBoxFileData/2014/12/03/6264133/statut.pdf, посећено 22. новембра 2018. године.
} 
после подне, и рано увече, а информтивни, културни и забавни садржаји намењени одраслима током вечери (Mihelj \& Huxtable, 2018: 216-240). О рутинизацији свакодневице и телевизијском времену и стварању „програмских навика”, говори и Ердеи: „Било је планирано да се програм свакодневно емитује у трајању од два сата, од 19 до 21 сат, изузев уторка, а да се средом емитује и поподневни програм. Понедељак је требало да буде „спортски дан“, пошто су се давали прегледи спортских збивања током викенда. Средом би поподне био емитован дечији програм, а вече би било посвећено политичким садржајима. Четвртак би био резервисан за уметничка остварења, а субота и недеља за претежно забавни програм. Свакога дана у 20 часова био би емитован ТВ журнал, осим недељом, када би у исто време била приказивана емисија 'Седам дана у свету’. Сваког дана програм би се завршавао кратким вестима и метеоролошким извештајем" (Erdei, 2015: 417-418, према Leandrov, 1986: 21).

О прављењу дечијег програма на Телевизији Београд, Миодраг Илић говори као о часном и племенитом, али и сложеном и деликатном послу, који могу да остваре само највеће, често само националне телевизијске куће. Дилеме су бројне: како се обраћати деци, како их истовремено забављати и подучавати и сл. Оно што дечији програм мора да испуни су следећи критеријуми:

1. „Психолошка осмишљеност сценарија и озбиљно схватање детета као гледаоца;

2. Високи квалитет реализације, у којој не сме бити ничег лажног и претераног;

3. Заштита психе детета од могуће идентификације с нечим што је рањиво и болно;

4. Заштита психе детета од бруталности, ругоба и саблазни;

5. Активирање дечије свести и заинтересованости за појаве у природи и људским односима, помоћу забаве и игре, шале и песма;

6. Развијање маште и позитивних особина, ненаметљиво усађивање поштовања и љубави према свим људима, без обзира на пол, расу и веру;

7. Неговање осећања праведности" (Ilić, 2006: 73).

На првом Светском самиту о медијима за децу ${ }^{14}$ одржаном 1995. године, усвојена је Повеља о дечијој телевизији коју су потписали представници бројних земаља. Успостављени су следећи циљеви (Lemiš, 2006: 330-331):

1. Деца треба да прате програме високог квалитета који су осмишљени специјално за њих и који их не експлоатишу. Осим забаве, ови програми треба да омогуће деци да се максимално развијају, у физичком, менталном и друштвеном погледу.

2. Деца треба да чују, виде и изразе своје ставове, своју културу, језик и животна искуства помоћу телевизијских програма који афирмишу њихову личност, друштво и место у њему.

\footnotetext{
${ }^{14}$ Више о Светском самиту о медијима за децу на: http://cgms17.com/about-the-summit-2/, посећено 26. новембра 2018. године.
} 
3. Дечији програми треба да промовишу свест и поштовање према другим културама паралелно са свешћу и поштовањем према властитом културном наслеђу.

4. Дечији програми треба да буду широког спектра у погледу жанрова и садржаја, али не смеју да садрже неоправдане сцене насиља и секса.

5. Дечије програме треба емитовати у прописаним терминима, у доба када деца могу да прате програм, и/или их дистрибуирати преко широке мреже доступних медија и технологија.

6. Морају се обезбедити финансијска средства довољна да би се производили програми у складу са највишим стандардима.

7. Владе, као и продуцентске, дистрибуирајуће и финансирајуће организације треба да схвате значај и осетљивост локалне дечије телевизије и предузму кораке да је подрже и заштите уз промовисање дечијих програма на језицима и /или дијалектима мањина.

На основу мониторинга програма јавног медијског сервиса Србије, од јануара до јуна 2016. године, Вељановски закључује да је школски дечији програм квалитетан са становишта едукативности и занимљивости, али и вредности које промовише, као што су љубав, пријатељство, знање и учење. Скоро половина емисија намењена је деци узраста до 7 година, док је најмање оних чија су циљна група тинејџери, свега пет одсто (Veljanovski, 2016: 188). У истраживању које је Матић спровела током 2009. године, установљено је да у садржају дечијег програма доминирају цртани филмови. „На РТС 1 цртани филмови су чинили 87 одсто садржаја дечијег програма, 79 одсто на РТС 2... На британском каналу Би-Би-Си (ББЦ), цртани програми чине 15 одсто дечијег програма на Првом каналу и 8 одсто на Другом...” (Matić, 2009: 48). Ауторка је закључила да су деца „увелико занемарена публика домаће телевизије” (Matić, 2009: 47).

Овакав закључак биће проверен у истраживачком делу рада.

\section{2. Истраживање: \\ Дечији телевизијски програм јавног медијског сервиса Србије}

Предмет истраживања у раду је положај дечијег програма Јавног медијског сервиса Србије. Циљ рада је истражити квантитативну заступљеност дечијег програма у укупном програмском садржају, кроз анализу садржаја докумената, квантитативном статистичком и компаративном методом. Анализирани су и упоређени резултати истраживања Регулаторног тела за електронске медије (некадашња Републичка радиодифузна агенција), које је овлашћено да врши надзор над радом јавног сервиса, а који су представљени кроз годишње извештаје о испуњавању програмских и законских обавеза Радио-телевизије 
Србије од 2010. до 2017. године ${ }^{15}$. Истраживачко питање је да ли проценти емитованог дечијег програма на Јавном медијском сервису Србије задовољавају програмске стандарде у складу са регулативом?

Истраживање о гледаности телевизијских програма са националном покривеношћу у 2017. години показује да су највернији гледаоци телевизије припадници старије генерације, а уз телевизијске екране најмање времена проводе млади ${ }^{16}$. Подаци говоре и да је јавни медијски сервис Србије био најгледанија телевизија и код деце узраста од 4 до 14 година. Досег аудиторијума био је 26,9 одсто (166 хиљада деце дневно је гледало РТС). Од свих узрасних категорија, деца најмање времена проведу уз РТС - 22 минута дневно, али ипак је реч о најосетљивијој категорији друштва за које је телевизија важан агенс социјализације, због чега је и важно утврдити какав садржај та телевизија емитује.

На основу спроведеног истраживања током 2014. године ${ }^{17}$, анализе садржаја дечијег програма јавних сервиса, комерцијалних и кабловских емитера, интервјуа са уредницима овог програма и анализе ставова деце и родитеља о програму, аутори су уочили следеће проблеме: највећи проценат емитованог дечијег програма, 65 одсто, чинили су цртани филмови, а притом је програм неравномерно распоређен, jep се често емитује викендом, у блоковима. Честе су и репризе старих емисија, које уредници правдају потребом да се новим генерацијама представе ванвременске вредности, традиција и култура. Родитељи и деца оцењују да би дечији програм могао бити разноврснији, квалитетнији, примеренији социокултурном контексту, интерактивнији и везанији за образовни процес.

У Табели 1 и Табели 2 приказана је заступљеност дечијег програма у укупном програмском садржају, на основу истраживања Регулаторног тела за електронске медије чији су резултати приказани кроз годишње извештаје о испуњавању програмских и законских обавеза Радио-телевизије Србије. ${ }^{18}$

Табела 1. Статистика РТС 1 програма за период 2010-2017
\begin{tabular}{|c|c|}
\hline PTC 1 & $\begin{array}{c}\text { Дечији програм } \\
\text { (Проценат укупног } \\
\text { емисионог времена) }\end{array}$ \\
& $\%$ \\
\hline 2010 & 2,80 \\
\hline 2011 & 2,68 \\
\hline
\end{tabular}

\footnotetext{
${ }^{15}$ Извештаји о испуњењу законских и програмских обавеза Радио-телевизије Србије (2010, 2011, 2012, 2013, 2013, 2014, 2015, 2016, 2017), доступно на : http:/www.rem.rs/sr/izvestaji-i-analize/ izvestaji-i-analize-o-nadzoru-emitera, посећено 15. новембра 2018. године.

16 Подаци добијени на захтев. Јовановић, С. (2018). Гледаност телевизијских програма с националном покривеношћу у 2017. години - годишњи извештај. РТС - Центар за истраживање јавног мњења, програма и аудиторијума, стр. 9-10.

${ }^{17}$ Анализа телевизијских програма за децу (2014). Београд: Удружење новинара Србије, УНИЦЕФ доступно на: https://www.unicef.org/serbia/publikacije/analiza-televizijskih-programa-za-decu-usrbiji, посећено 25. новембра 2018. године.

${ }^{18}$ Емисионо време је укупно време емитовања програма, свих садржаја, током 24 сата 365 дана у години.
} 


\begin{tabular}{|l|l|}
\hline 2012 & 2,79 \\
\hline 2013 & 1,51 \\
\hline 2014 & 1,29 \\
\hline 2015 & 1,35 \\
\hline 2016 & 0,49 \\
\hline 2017 & 0,39 \\
\hline
\end{tabular}

Табела 2. Статистика РТС 2 програма за период 2010-2017

\begin{tabular}{|c|c|}
\hline РТC 2 & $\begin{array}{c}\text { Дечији програм } \\
\text { (Проценат укупног } \\
\text { емисионог времена) } \\
\%\end{array}$ \\
\hline 2010 & 5,96 \\
\hline 2011 & 6,33 \\
\hline 2012 & 6,85 \\
\hline 2013 & 6,19 \\
\hline 2014 & 4,77 \\
\hline 2015 & 6,40 \\
\hline 2016 & 12,64 \\
\hline 2017 & 10,63 \\
\hline
\end{tabular}

Предмет рада није истраживање комерцијалних емитера, али у циљу сагледавања шире слике медијске сцене у Србији, у наставку је дато и истраживање њиховог програма, које такође спроводи Регулаторно тело за електронске медије.

Табела 3. Статистика комерцијалних телевизија за период 2015-2017 19

\begin{tabular}{|c|c|c|c|c|}
\hline \multicolumn{3}{|c|}{$\begin{array}{c}\text { Дечији програм } \\
\text { (Проценат укупног емисионог времена) } \\
\%\end{array}$} & \multirow[b]{2}{*}{ РТВ Пинк } & \multirow[b]{2}{*}{ Хепи ТВ } \\
\hline & O2. ТВ/ТВ Б92 & Прва & & \\
\hline 2015 & 7,14 & 1,88 & 0,11 & 1,08 \\
\hline 2016 & 16,41 & 1,06 & 0 & 0,16 \\
\hline 2017 & 16,68 & 0,8 & 0 & 0 \\
\hline
\end{tabular}

Осим на О2.ТВ, некадашњој Б92.ТВ, која има високе проценте емитованог дечијег програма (углавном цртане филмове), остале комерцијалне телевизије и ако имају, имају мање од два одсто дечијег програма.

С обзиром да квоте одређене врсте програма не постоје, тешко је рећи да ли је учешће дечијег програма у укупном емисионом времену задовољавајуће, али у поређењу са најстаријим јавним сервисом на свету, британским јавним сервисом, мало је емисија посвећених деци на РТС-у. Према истраживању програмског статуса РТС-а као јавног сервиса у аудиторијуму ${ }^{20}, 52,3$ одсто грађана слаже

\footnotetext{
${ }^{19}$ Извештаји о испуњењу законских и програмских обавеза комерцијалних емитера $(2015,2016$, 2017), доступно на : http://www.rem.rs/sr/izvestaji-i-analize/izvestaji-i-analize-o-nadzoru-emitera, посећено 15. новембра 2018. године.

20 Истраживање Центара за истраживање јавног мњења, програма иаудиторијума Радио телевизије Србије, Програмски и медијски статус РТС-а као јавног сервиса у аудиторијуму,
} 
се са ставом да РТС негује емисије за децу и младе. Ово мишљење не дели и Регулаторно тело за електронске медије које у свом годишњем извештају ${ }^{21}$ наводи да јавни медијски сервис не испуњава у довољној мери обавезе које произлазе из чланова 7, 8. и 9. Закона о јавним медијским сервисима, и да је дужан да повећава уделе програма намењеног осетљивим групама, као што су деца и омладина. Регулаторно тело за електронске медије закључује да је уредништво РТС-а и ове године остало при програмској концепцији која подразумева атрактивне садржаје велике гледаности на РТС1 (информативни, серијски и филмски програм), без намере да програмску шему првог канала обогати квалитетним културноуметничким, дечијим, верским или научно-образовним емисијама, које се често приказују у неприкладним терминима на РТС-у 2.

Истраживање Анализа телевизијских програма за децу из 2014. године доноси и објашњење уреднице дечијег програма јавног сервиса о оваквом положају програма. Наташа Дракулић истиче да је највећа препрека за развој дечијег програма недостатак финансијских средстава, јер је реч о некомерцијалном садржају, који не привлачи оглашиваче. Следећи проблем је несталност програмске шеме, посебно РТС-а 2, на ком се и емитује највећи проценат дечијих емисија, а најчешће због спортских или преноса заседања Скупштине Србије.

Упркос проблемима, Дракулић истиче да је квалитет дечијег програма задовољавајући и истиче: „На пример, годинама успешно учествујемо у ЕБУ (Европска радиодифузна унија, прим. аут.) пројектима за децу, где у сарадњи са њиховим продуцентима сваке године реализујемо једну играну драму и једну документарну емисију које су на редовном емитовању европских јавних сервиса и увек су запажене" (Р. Л., 2012: 25).

Од 1. новембра 2018. године почело је емитовање новог кабловског програма РТС Полетарац намењеног деци и младима. Програм репризира култне емисије програма за децу Телевизије Београд као и актуелне емисије РТС-а.

\section{Закључак}

Анализирајући проценте емитованог дечијег програма на РТС-у 1 и РТС-у 2, може се закључити да је у последње две године проценат емитованог дечијег програма порастао и да је по први пут о овој деценији премашио 10 процената (2016 - 13,13 одсто и 2017 - 11,02 одсто). У годинама пре тога дечији програм је био занемариван (2013 - 7,7 одсто, 2014 - 6,06 одсто и 2015 - 7,75 одсто). Упркос укупном увећању процената емитованог дечијег програма на каналима јавног медијског сервиса Србије, забрињава тренд смањења броја емисија намењених деци на Првом програму (2015 - 1,35 одсто, 2016 - 0,49 одсто и 2017 - 0,39 одсто), на рачун повећања удела дечијег програма на Другом програму јавног медијског

\footnotetext{
добијено је на захтев ауторки рада.

${ }^{21}$ Доступан на: http://rem.rs/uploads/files/RDUS-i-RDUV/RTS\%20\%20izve\%C5\%A1taj\%20za\%20 2017\%20godinu.pdf, посећено 15. октобра 2018. године.
} 
сервиса који има несталну програмску шему због честих преноса скупштинских заседања и спортских догађаја. И у овом случају је доказано: „Јавни медијски сервис Србије, када је реч о телевизији, концепцијски је тако постављен да Први програм емитује углавном информативне и забавне садржаје, док Други програм карактерише разноврсност програмских садржаја (Михајлов Прокоповић и Вујовић, 2012: 357). Иако квоте жанровске заступљености појединих врста програма нису прописане, Републичко Регулаторно тело за електронске медије оцењује да јавни медијски сервис не испуњава у довољној мери обавезе које произилазе из Закона о јавним медијским сервисима, и да је дужан да повећава уделе програма намењеног осетљивим групама, као што су деца и омладина.

Замерке упућене британском и српском јавном сервису на рачун дечијег програма су веома сличне: недостатају оригинални и квалитетни програми, емисије везаније за образовни процес и дечији програми који су у складу са социокултурним контекстом, што би деци омогућило лакшу идентификацију.

Осим покретања првог специјализованог канала намењеног деци - РТС Полетарац, који репризира култне и актуелне дечије емисије и који ће без сумње допринети повећању удела дечијег програма на јавном медијском сервису, потребно је да РТС има више оригиналних и квалитетних дечијих емисија, које ће својом интерактивношћу привући публику, и које ће редовно бити емитоване у примеренијим терминима. Такође, нужна је и усклађеност са савременим интересовањима деце и образовним програмима. Неопходно је и да јавни медијски сервис што више користи дигиталне платформе за емитовање, које су деци све доступније и једноставније за коришћење. На том путу дигиталне трансформације РТС је 2018. године покренуо РТС Планету, мултимедијске интернет услуге, која омогућава уживо праћење свих програма јавног медијског сервиса Србије, као и одлазак у архив РТС-а, који чува емисије намењене деци, снимане још од настанка Телевизије Београд.

\section{Literatura}

Analiza televizijskih programa za decu (2014). Beograd: Udruženje novinara Srbije, UNICEF.

Children's content review: update, available at: https://www.ofcom.org.uk/_data/assets/ pdf_file/0023/116519/childrens-content-review-update.pdf

Izveštaj o ispunjenju zakonskih i programskih obaveza komercijalnih emitera $(2015,2016$, 2017), dostupno na: http://www.rem.rs/sr/izvestaji-i-analize/izvestaji-i-analize-onadzoru-emitera.

Izveštaj o ispunjenju zakonskih i programskih obaveza Radio - televizije Srbije (2010, 2011, 2012, 2013, 2013, 2014, 2015, 2016, 2017), dostupno na: http://www.rem.rs/ sr/izvestaji-i-analize/izvestaji-i-analize-o-nadzoru-emitera

Erdei, I. (2015). Novi život na „,malom ekranu” i oko njega: počeci televizije u socijalističkoj Jugoslaviji (1955-1970). Etnoantropološki problemi, 10(2), 405-426.

Ilić, M. (2006). Rađanje televizijske profesije. Beograd: Klio. 
Jačanje medijske slobode - Analiza medijskog tržišta u Srbiji (2015). Ipsos Strategic Marketing, dostupno na: http://www.rem.rs/uploads/files/PDF/6529-Analiza\%20 medijskog\%20trzista\%20u\%20Srbiji\%20-\%20final.pdf

Jovanović, S. (2018). Gledanost televizijskih programa s nacionalnom pokrivenošću u 2017. godini - godišnji izveštaj. Beograd: RTS - Centar za istraživanje javnog mnjenja, programa i auditorijuma.

Josifović, S. i Senić, N. (2011). Programski i medijski status RTS-a kao javnog servisa u auditorijumu. Beograd: RTS - Centar za istraživanje javnog mnjenja, programa i auditorijuma.

Leandrov, I. (1986). Pre početka. Beograd: Televizija Beograd.

Lemiš, D. (2008). Deca i televizija. Beograd: Klio.

Matić, J. (2009). Raznovrsnost TV programa u Srbiji. U: D. Valić Nedeljković (ur.). Medijski skener (24-69). Novi Sad: Novosadska novinarska škola.

Mihajlov Prokopović, A. i Vujović, M. (2012). Nauka u programu javnog medijskog servisa Srbije. Kriza i perspektiva znanja i nauke, 352-365.

Mihelj, S., \& Huxtable, S. (2018). From media systems to media cultures: Understanding socialist television. London: Cambridge University Press.

Pravilnik o merilima za utvrđivanje visine naknade za emitovanje radio i/ili televizijskog programa ("Sl. glasnik RS", br. 50/2009).

R. L. (2012). Nismo komercijalni program, Link, časopis za profesionalce u medijima, broj 105, 2012.

Statut javne medijske ustanove Radio televizije Srbije, dostupan na: http:/www.rts.rs/ upload/storyBoxFileData/2014/12/03/6264133/statut.pdf

Veljanovski, R. (2005). Javni RTV servis u službi građana. Beograd: Klio.

Veljanovski, R. (2016). Analiza programajavne medijske ustanove Radio-televizije Srbije. U: D. Valić Nedeljković i dr. Ostvarivanje javnog interesa u javnim medijskim servisima u Srbiji (151-218). Novi Sad: Novosadska novinarska škola.

Zakon o elektronskim medijima ("Sl. glasnik RS”, br. 83/2014 i 6/2016 - dr. zakon).

Zakon o javnim medijskim servisima (“Sl. glasnik RS”, br. 83/2014, 103/2015 i 108/2016).

Zakon o javnom informisanju i medijima (“Sl. glasnik RS”, br. 83/2014 i 58/2015).

\title{
ANALYSIS OF THE CHILDREN'S TELEVISION PROGRAM OF THE PUBLIC MEDIA SERVICE OF SERBIA
}

\author{
Marija Vujović, Anka Mihajlov Prokopović \\ University of Niš, Faculty of Philosophy, \\ Department of Communication and Journalism
}

Apstract: Children's television program is an elite and expensive program designed for the most sensitive and most demanding auditorium - children. It 
represents the prestige of a television company, but also the program obligation of the Public Media Service of Serbia. Its representation and diversity could be an indicator of the development of the public service. The subject of the research in the work is the position of the children's program of the Public Media Service of Serbia. The aim of the paper is to investigate the quantitative representation of the children's program in the overall program content. The analysis was carried out on the basis of research results of the Regulatory body for electronic media of the Republic of Serbia. The research question is whether the scope of broadcast children's program at the Public Media Service of Serbia meet program standards in accordance with the regulations? The paper will also analyze the regulation in Serbia that refers to the children's program. The methodology in the paper is the analysis of the contents of documents, the quantitative statistical method and the comparative method. The results show that the public media service does not adequately fulfill the obligation to broadcast a program intended for children.

Keywords: children's program, public media service of Serbia, program standards

\section{Citiranje članka:}

Vujović, M. i Mihajlov Prokopović, A. (2018). Analiza dečijeg televizijskog programa javnog medijskog servisa Srbije. Godišnjak za pedagogiju, 3(2), 19-30 